\title{
Importance of osteoprotegrin and receptor activator of nuclear factor $\kappa B$ in breast cancer response to hepatocyte growth factor and the bone microenvironment in vitro
}

\author{
SIONED OWEN ${ }^{1}$, ANDREW J. SANDERS ${ }^{1}$, MALCOLM D. MASON $^{2}$ and WEN G. JIANG ${ }^{1}$ \\ ${ }^{1}$ Cardiff China Medical Research Collaborative, ${ }^{2}$ Section of Oncology and Palliative Medicine, \\ School of Medicine, Cardiff University, Cardiff, CF14 4XN, UK
}

Received July 24, 2015; Accepted September 11, 2015

DOI: $10.3892 /$ ijo.2016.3339

\begin{abstract}
Osteoprotegrin (OPG), receptor activator of nuclear factor $\kappa \mathrm{B}(\mathrm{RANK})$ and RANK ligand (RANKL) are signal transducers which have pleiotropic actions. Each tumour necrosis factor receptor superfamily member has unique structural attributes which directly couples them to signalling pathways involved in cell proliferation, differentiation and survival. Previous studies have clinically linked OPG, RANK and RANKL to increasing tumour burden, metastatic bone involvement and estrogen status. This study aimed to establish the potential implications of targeting endogenously produced OPG and RANK in the osteotropic breast cancer cell line MDA-MB-231 in vitro. Subsequently this study also aimed to explore the potential links between these molecules with regards to hepatocyte growth factor (HGF) signalling and extracted bone proteins (BME). OPG and RANK expression was successfully suppressed using hammerhead ribozyme technology. Subsequently effects were explored in MDA-MB-231 cell proliferation, matrix adhesion, migration and invasion in vitro function assays. Reduced OPG expression resulted in increased breast cancer cell migration and invasion. These increases, particularly invasion, appeared to however be reduced under the influence of the exogenous stimuli (HGF and BME). In contrast, suppression of RANK in MDA-MB-231 breast cancer cells resulted in decreased cancer cell proliferation, matrix-adhesion, motility and invasion with little cumulative effect being noted after the addition of exogenous stimuli. The complexity of the bone environment underpins the vast number of soluble factors and signalling pathways which can influence osteotropic cancer behaviour and progression. Further work into elucidating all the path-
\end{abstract}

Correspondence to: Dr Sioned Owen, Cardiff China Medical Research Collaborative, School of Medicine, Cardiff University, Cardiff, CF14 4XN, UK

E-mail: owens15@cardiff.ac.uk

Key words: breast cancer, bone metastasis, osteoprotegrin, RANK, hepatocyte growth factor, bone microenvironment ways affected could potentially lead to better identification of those patients most at risk.

\section{Introduction}

Despite advances in breast cancer care and regimens it still imposes a large burden on health care systems around the world, especially when metastatic disease is detected. Breast cancer is associated with latent disease and high relapse rate which can often present clinically as bone metastases (1). The majority of breast cancer related bone metastases present as the osteolytic phenotype, which is identified by loss of bone density accompanied by an increase in osteoclast numbers (2).

The variability in metastatic cancer patterns is undoubtedly influenced by the molecular and cellular characteristics of both the tumour cells and the tissue in which they invade (3). It was Stephen Paget, through autopsy data, who first established a link between breast cancer metastases and the bone, giving rise to his 'seed and soil' hypothesis (4). As this theory has evolved the metastatic cascade has been shown to be a highly inefficient multistep process which involves a wide variety of factors including integrins, matrix metalloproteinases and tumour secreted factors $(5,6)$. Invasion into the bone results in the release of a variety of factors, in addition to those produced by the tumour cells, which generate a feedback loop to the tumour cells enhancing tumour cell dormancy, survival and growth in the bone marrow and the microenvironment (7). However, much still remains unknown of how these factors interact with each other and the disseminating tumour cells to culminate in bone metastases and how best these can be targeted in therapies.

Members of the tumour necrosis factor receptor superfamily (TNFRSF) osteoprotegrin (OPG), receptor activator of nuclear $\kappa \mathrm{B}$ (RANK) and RANK ligand (RANKL) have been shown to be integral molecular regulators in the bone remodelling cycle. The RANKL:OPG ratio is a major determinant of bone mass, both physiologically and patho-physiologically (8). Osteoblasts have been shown to incorporate both pro- and antibone resorptive signals and thus control the bone remodelling response by altering the expression of RANKL and secretion of its inhibitor OPG $(9,10)$. RANK, expressed on the surface 
of osteoclasts, through binding to RANKL, expressed on the surface of osteoblasts, promotes osteoclast differentiation and maturation, thus promoting bone resorption. OPG, a soluble decoy receptor for RANKL, secreted by osteoblasts, inhibits RANK interaction thus promoting osteoblast survival and hence bone formation. However, OPG, RANK and RANKL have also been linked to tumourigenesis in a variety of cancers which have a predisposition to form bone metastases. Both circulating RANKL and OPG have previously been identified as novel biomarker candidates for predicting bone metastases in breast cancer patients $(11,12)$. Quantitative PCR and immunohistochemistry have shown negative correlations between estrogen receptor status and levels of OPG, RANK and RANKL (13).

There has also been some in vitro evidence to suggest that endogenously produced OPG, from breast cancer cells or bone marrow stromal cells, can also promote breast cancer cell survival through inhibition of TNF related apoptosis inducing ligand (TRAIL) $(14,15)$. This inhibition occurs as OPG acts as a decoy receptor for the TRAIL receptor, though with less affinity than that seen with RANKL, therefore blocking the apoptotic pathway. This prevention of apoptosis through TRAIL inhibition has also been shown, in the MDA-MB-231 breast cancer cell line, to result in the up regulation of RANKL thus contributing to the 'vicious' bone cycle between tumour cells and bone cells by further enhancing osteolysis and the release of growth factors which can further enhance tumour growth (16).

The bone microenvironment is a complex combination of cells, growth factors and cytokines. Trying to isolate the factors which are crucial components in facilitating the establishment of bone metastases is a substantial challenge. One of the factors, which have been shown to influence tumourigenesis traits and cancer progression is hepatocyte growth factor (HGF), also known as scatter factor (17-19). Despite its discovery 30 years ago its wide and complex influences on cancer cells, the metastatic cascade and tumour microenvironments remain under intense investigation for potential new targeted therapies $(20,21)$.

In the present study the targeting of OPG and RANK in bone metastasis derived breast cancer cells (MDA-MB-231 cells) was explored. These manipulated cells were then exposed to the influences of HGF and a bone protein-like environment to explore the potential implications on HGF signalling thus potentially altering disease progression.

\section{Materials and methods}

Ethics statement. All research involving human tissue was carried out under the Panel B Bro Taf Research Ethics Committee for the Bro Taf Health Board, Cardiff, UK. All data were analysed anonymously and informed written consent was given (Bro Taf Health Board, 2007).

Cell lines and treatments. Human breast cancer MDA-MB-231 cells were purchased from the American Type Culture Collection (ATCC, Rockville, MD, USA). MDA-MB-231 cells were maintained in Dubecco's modified Eagle's medium (DMEM) (PAA Laboratories Ltd., Somerset, UK) supplemented with penicillin, streptomycin and $10 \%$ foetal calf serum (PAA Laboratories Ltd.) and incubated at $37^{\circ} \mathrm{C}, 5 \% \mathrm{CO}_{2}$ and
95\% humidity. Hepatocyte growth factor was a kind gift from Dr T. Nakamura (Osaka University Medical School, Osaka, Japan). Bone proteins were extracted from fresh human bone tissues collected immediately after hip replacement under the local health board ethics committee guidelines. Bones were crushed at ice cold temperatures and subsequently processed in a Bioraptor sonicator (Wolf Laboratories, York, UK) to extract matrix proteins (22). Throughout this study HGF was used at a final concentration of $40 \mathrm{ng} / \mathrm{ml}$, whilst the BME extract from the femoral heads was used at a final concentration of $50 \mu \mathrm{g} / \mathrm{ml}$.

Generation of MDA-MB-231 breast cancer cells with suppressed OPG or RANK expression. OPG and RANK expression were targeted in human MDA-MB-231 breast cancer cells using ribozyme transgenes specifically generated to target and cleave each transcript. This methodology has been previously reported $(23,24)$. Briefly, ribozyme transgene sequences were designed based on Zukers predicted secondary mRNA structure using Zukers RNA Mfold program (25) and were synthesised by Sigma-Aldrich (Poole, Dorset, UK) (Table I). Ribozymes were subsequently cloned into a pEF6/V5-His-TOPO plasmid vector (Invitrogen, Paisley, UK). Both control pEF6 plasmids, containing no insert, and plasmids containing the relevant ribozyme transgene were transfected separately into MDA-MB-231 breast cancer cells using electroporation. Following transfection, these cells underwent a selection period and subsequent verification of OPG or RANK knockdown. Cells containing the ribozyme transgenes were termed MDA-MB-231 $1^{\text {OPGKD }}$ or MDA-MB-231 $1^{\text {RANKKD }}$ and were compared throughout the study to control MDA-MB-231 cells containing the closed control plasmid, termed MDA-MB-231 $1^{\mathrm{pEF} 6}$.

$R N A$ extraction and reverse transcription-polymerase chain reaction $(R T-P C R)$. Cells were grown to confluence in a $25-\mathrm{cm}^{2}$ flask before RNA was extracted using total RNA isolation (TRI) reagent (Sigma) in accordance with the supplied protocol. RNA was subsequently quantified using a spectrophotometer (Implen Nanophotometer, Muchen, Germany) configured to detect single strand RNA $(\mu \mathrm{g} / \mu \mathrm{l})$. RNA was standardised to $500 \mathrm{ng}$ and used as a template to generate cDNA using high capacity cDNA reverse transcription kit (Applied Biosystems, Manchester, UK). Following cDNA synthesis, sample quality and uniformity was normalised against GAPDH expression (primer details in Table II). The amplifluor system (Intergen Inc., New York, NY, USA) was utilised with qPCR Master Mix (ABgene, Surrey, UK). Conditions for qPCR were; $15 \mathrm{~min}$ initial $95^{\circ} \mathrm{C}$ period followed by 60 cycles of $95^{\circ} \mathrm{C}$ for $15 \mathrm{sec}$, $55^{\circ} \mathrm{C}$ for $60 \mathrm{sec}$ and $72^{\circ} \mathrm{C}$ for $20^{\circ} \mathrm{C} \mathrm{sec}$.

SDS-PAGE and western blotting. Protein was extracted from a confluent $75-\mathrm{cm}^{2}$ tissue culture flask of MDA-MB-231 cells. Cells were detached and lysed in a buffer comprising $50 \mathrm{mM}$ Tris-base, $5 \mathrm{mM}$ EGTA, $150 \mathrm{mM} \mathrm{NaCl}, 1 \%$ Triton X-100, $100 \mu \mathrm{g} / \mathrm{ml}$ PMSF, $10 \mu \mathrm{g} / \mathrm{ml}$ aprotinin, $10 \mu \mathrm{g} / \mathrm{ml}$ leupeptin, $5 \mathrm{mM}$ sodium vanadate and $50 \mathrm{mM}$ sodium fluoride on a rotor wheel for $1 \mathrm{~h}$ before removal of insolubles through centrifugation at 13,000 g. The Bio-Rad DC protein assay kit (Bio-Rad Laboratories, CA, USA) was used to quantify protein levels in 
Table I. Primers designed for ribozyme synthesis.

\begin{tabular}{|c|c|c|c|}
\hline Target & Ribozyme & Primer name & Primer sequence (5'-3') \\
\hline & & $\mathrm{T} 7 \mathrm{~F}$ & TAATACGACTCACTATAGGG \\
\hline & & RBBMR & TTCGTCCTCACGGACTCATCAG \\
\hline & & RBTPF & CTGATGAGTCCGTGAGGACGAA \\
\hline \multirow[t]{6}{*}{ OPG } & OPG ribozyme 1 & OPGRIB1F & $\begin{array}{l}\text { CTGCAGCTCCTTGCACACGGGGCTGCAGTATACT } \\
\text { GATGAGTCCGTGAGGA }\end{array}$ \\
\hline & & OPGRIB1R & $\begin{array}{l}\text { ACTAGTACACAGACAGCTGGCACACCAGTGACGA } \\
\text { GTGTTTCGTCCTCACGGACT }\end{array}$ \\
\hline & OPG ribozyme 2 & OPGRIB2F & $\begin{array}{l}\text { CTGCAGACACTGCAATTTGTGTGTTTTCTACTGGG } \\
\text { TGCTTTACTGATGAGTCCGTGAGGA }\end{array}$ \\
\hline & & OPGRIB2R & $\begin{array}{l}\text { ACTAGTTCTTCTCAAATGAGACGTCATTTCGTCCT } \\
\text { CACGGACT }\end{array}$ \\
\hline & OPG ribozyme 3 & OPGRIB3F & $\begin{array}{l}\text { CTGCAGGGTAACATCTATTCCACATTTTGAGTTCTG } \\
\text { ATGAGTCCGTGAGGA }\end{array}$ \\
\hline & & OPGRIB3R & $\begin{array}{l}\text { ACTAGTTCCGGAAACAGTGAATTTCGTCCTCACGG } \\
\text { ACT }\end{array}$ \\
\hline \multirow[t]{10}{*}{ RANK } & RANK ribozyme 1 & RANKRIB1F & $\begin{array}{l}\text { CTGCAGCGCGCGGGGCCATGGCGCGGCTGATGA } \\
\text { GTCCGTGAGGA }\end{array}$ \\
\hline & & RANKRIB1R & $\begin{array}{l}\text { ACTAGTGCCGCGGCGCCGCCAGCCTGTTTCGTCC } \\
\text { TCACGGACT }\end{array}$ \\
\hline & RANK ribozyme 2 & RANKRIB2F & $\begin{array}{l}\text { CTGCAGCTCATAATGCTTCTCACTGGCTGATGAGT } \\
\text { CCGTGAGGA }\end{array}$ \\
\hline & & RANKRIB2R & $\begin{array}{l}\text { ACAGTCTTTGCAGATCGCTCCTCCATGTTTCGTCC } \\
\text { TCACGGACT }\end{array}$ \\
\hline & RANK ribozyme 3 & RANKRIB3F & $\begin{array}{l}\text { CTGCAGGTACTTTCCTGGTTCACATTTGTCTGATG } \\
\text { AGTCCGTGAGGA }\end{array}$ \\
\hline & & RANKRIB3R & $\begin{array}{l}\text { ACTAGTAGCATTATGAGCATCTGGGACGGTGCTGT } \\
\text { TTCGTCCTCACGGACT }\end{array}$ \\
\hline & RANK ribozyme 4 & RANKRIB4F & $\begin{array}{l}\text { CTGCAGTGCTGACCAAAGTTTGCCGTGTGTGCTG } \\
\text { ATGAGTCCGTGAGGA }\end{array}$ \\
\hline & & RANKRIB4R & $\begin{array}{l}\text { ACTAGTGGAGTCCTCAGGTGACAGTTGTGTCAGTT } \\
\text { TCGTCCTCACGGAC }\end{array}$ \\
\hline & RANK ribozyme 5 & RANKRIB5F & $\begin{array}{l}\text { CTGCAGCTGGCATCTTCGCCTTGTGCGTAGGCTG } \\
\text { ATGAGTCCGTGAGGA }\end{array}$ \\
\hline & & RANKRIB5R & $\begin{array}{l}\text { ACTAGTGTCAGGGCACATGTGTAGGAGGTGGTTTC } \\
\text { GTCCTCACGGACT }\end{array}$ \\
\hline
\end{tabular}

each sample and samples were subsequently standardised to $2 \mathrm{mg} / \mathrm{ml}$ and diluted in $2 \mathrm{X}$ concentrate Laemmli sample buffer (Sigma) before being boiled for $5 \mathrm{~min}$. Samples were loaded onto a $10 \%$ acrylamide gel and separated electrophoretically. Following separation the proteins were blotted onto a PVDF membrane (Merck-Millipore, Feltham, UK). Proteins were detected using the Merck-Millipore SNAP i.d. protein detection system. OPG expression was detected using anti-OPG antibody [R\&D Systems, Abingdon, UK (BAF805)], RANK expression was detected using anti-RANK antibody [Santa
Cruz Biotechnology, Inc., CA, USA (sc-9072)]. To assess uniformity of the samples GAPDH expression was also detected using anti-GAPDH antibody [Santa Cruz Biotechnology, Inc. (sc-32233)]. Following binding of the primary antibody, the membranes were probed with peroxidase conjugated anti-goat (OPG), anti-rabbit (RANK) or anti-mouse (GADPH) secondary antibodies (Sigma). Expression was visualised using the Luminata chemiluminescence detection kit (MerckMillipore) and detected using a UVIProChem camera system (UVItec Ltd., Cambridge, UK). 
Table II. Primers for conventional RT-PCR and real-time qPCR.

\begin{tabular}{|c|c|c|c|c|}
\hline Gene & Primer name & Primer sequence (5'-3') & $\begin{array}{l}\text { Optimal annealing } \\
\text { temperature }\left({ }^{\circ} \mathrm{C}\right)\end{array}$ & $\begin{array}{l}\text { Product } \\
\text { size }(b p)\end{array}$ \\
\hline \multirow[t]{5}{*}{ OPG } & OPGF8 & GAACCCCAGAGCGAAATACA & 55 & 509 \\
\hline & OPGR8 & CGGTAAGCTTTCCATCAAGC & & \\
\hline & OPGF1 & GTTCTGCTTGAAACATAGGAG & 55 & 115 \\
\hline & OPGZR1 & ACTGAACCTGACCGTACACGTCT & & \\
\hline & & CATTTGAGAAGAACC & & \\
\hline \multirow[t]{5}{*}{ RANK } & RANKF9 & CAGAGCACAGTGGGTTCAGA & 55 & 462 \\
\hline & RANKR9 & GATGATGTCGCCCTTGAAGT & & \\
\hline & RANKF2 & TCTGATGCCTTTTCCTCCAC & 55 & 119 \\
\hline & RANKZR2 & ACTGAACCTGACCGTACATGGCA & & \\
\hline & & GAGAAGAACTGCAAA & & \\
\hline \multirow[t]{5}{*}{ RANKL } & RANKLF9 & GACTCCATGAAAATGCAGAT & 55 & 500 \\
\hline & RANKLR9 & TCCTTTCATCAGGGTATGAG & & \\
\hline & RANKLF1 & AAGGAGCTGTGCAAAAGGAA & 55 & 74 \\
\hline & RANKLZR1 & ACTGAACCTGACCGTACAATCCA & & \\
\hline & & CCATCGCTTTCTCTG & & \\
\hline \multirow[t]{5}{*}{ GAPDH } & GAPDHF10 & AGCTTGTCATCAATGGAAAT & 55 & 593 \\
\hline & GAPDHR10 & CTTCACCACCTTCTTGATGT & & \\
\hline & GAPDHF & CTGAGTACGTCGTGGAGTC & 55 & 93 \\
\hline & GAPDHZR & ACTGAACCTGACCGTACACAGAG & & \\
\hline & & ATGATGATGACCCTTTTG & & \\
\hline \multirow[t]{3}{*}{ PDPL } & PDPLF & GAATCATCGTTGTGGTTATG & 55 & \\
\hline & PDPLZR & ACTGAACCTGACCGTACACTTTCA & & \\
\hline & & TTTGCCTATCACAT & & \\
\hline
\end{tabular}

ACTGAACCTGACCGTACA represents the $\mathrm{Z}$ sequence.

In vitro cell proliferation assay. An in vitro cell proliferation assay was used to examine the impact of OPG or RANK suppression on cell proliferation. Cells were seeded into two 96-well plates at a seeding density of $3 \times 10^{3}$ cells/well with or without treatment and incubated for 1 and 5 days. Following incubation, cells were fixed in $4 \%$ formaldehyde (v/v) and stained with $0.5 \%$ crystal violet (w/v). Subsequently, $10 \%$ acetic acid (v/v) was used to extract the crystal violet stain and cell density determined through spectrophotometric analysis using a Bio-Tek Elx800 multi-plate reader (Bio-Tek Instruments Inc., VT, USA).

In vitro Matrigel matrix adhesion assay. Cell-matrix adhesion was assessed using a modified in vitro Matrigel adhesion assay (26). In brief, wells in a 96-well plate were pre-coated with $5 \mu \mathrm{g}$ of Matrigel (BD Matrigel matrix, Matrigel basement membrane matrix, Biosciences). Cells were seeded at $4.5 \times 10^{4}$ cells/well with or without treatment and left to adhere to the Matrigel for $40 \mathrm{~min}$ at $37^{\circ} \mathrm{C}$ with $5 \% \mathrm{CO}_{2}$. Adherent cells were fixed in $4 \%$ formaldehyde (v/v) and stained with $0.5 \%$ crystal violet (w/v). Subsequently, adherent cells were visualised under the microscope and representative images captured for analysis.

In vitro cell motility assay. Cell motility was assessed using a cytodex-2 bead motility assay as previously described $(27,28)$. In brief, $1 \times 10^{6}$ cells were incubated in $10 \mathrm{ml}$ of complete medium supplemented with $20 \mathrm{mg}$ of cytodex-2 beads. The following day, beads were washed twice with complete medium before being resuspended, added to the 96-well plate with or without treatment and incubated for $4 \mathrm{~h}$ at $37^{\circ} \mathrm{C}$ with $5 \% \mathrm{CO}_{2}$. Migrated cells were fixed in $4 \%$ formaldehyde $(\mathrm{v} / \mathrm{v})$ and stained with $0.5 \%$ crystal violet (w/v). Subsequently, adherent cells were visualised under the microscope and representative images captured for analysis.

In vitro Matrigel cell invasion assay. Cell invasiveness was assessed using an in vitro Matrigel invasion assay modified from refs. 29,30. In brief, transwell inserts containing 8- $\mu \mathrm{m}$ pores (Falcon, 24-well format, Greiner Bio-One, Germany) were placed in a 24-well plate (Nunc, Greiner Bio-One) and coated with $50 \mu \mathrm{g}$ of Matrigel (BD Matrigel matrix, Matrigel 

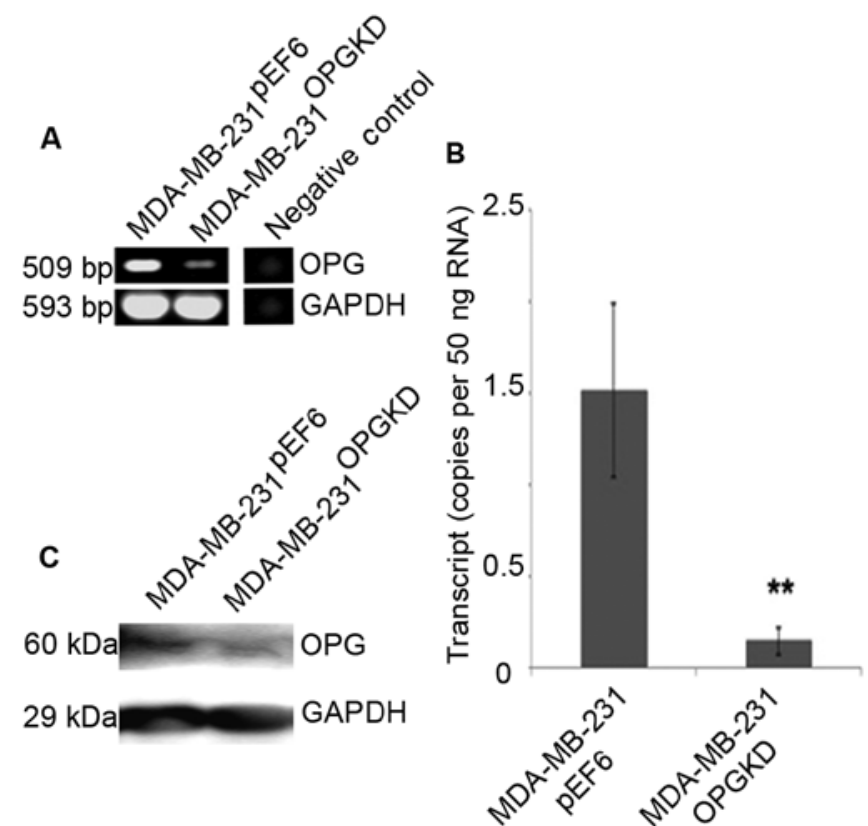
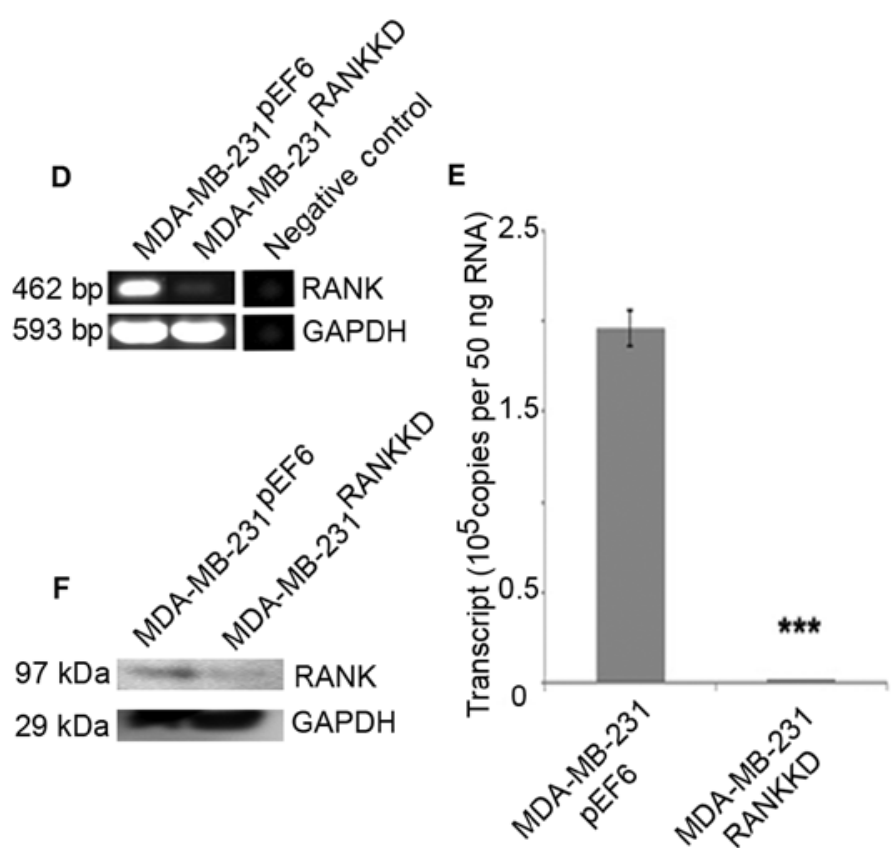

Figure 1. Verification of ribozyme transgene knockdown of OPG and RANK in MDA-MB-231 cells. Reduced expression of OPG and RANK were confirmed at a transcript level using RT-PCR (A and D) and qPCR (B and E) compared to the control cell line. Western blotting was used to confirm knockdown of OPG and RANK at a protein level (C and F respectively). PCR and western blotting were normalised against GAPDH. Representative images and data shown. ${ }^{* * *} \mathrm{p} \leq 0.01,{ }^{* * * *} \mathrm{p} \leq 0.001$.

basement membrane matrix, Biosciences). Subsequently $2 \times 10^{4}$ cells/insert were added to the insert and $1 \mathrm{ml}$ of medium was added to the bottom of the 24 -well plate to sustain any invaded cells. The plate was incubated for 3 days at $37^{\circ} \mathrm{C}$ with $5 \% \mathrm{CO}_{2}$ after which inserts were cleaned to remove any non-invaded cells, before invaded cells were fixed in $4 \%$ formaldehyde (v/v) and stained with $0.5 \%$ crystal violet (w/v). Subsequently, invaded cells were visualised under the microscope and representative images captured for analysis.

Statistical analysis. The Sigma plot 11.0 statistical software package was used to assess statistical differences between the OPG or RANK suppressed MDA-MB-231 cells compared to the pEF6 vector control MDA-MB-231 cells using the Student's two tailed t-test or non-parametric Mann-Whitney $\mathrm{U}$ test. Experimental procedures were repeated a minimum of 3 independent times. Data represent mean values \pm SEM, p-values of $\leq 0.05$ were regarded as statistically significant.

\section{Results}

Expression of OPG and RANK has previously been established in three breast cancer cell lines (31). There are also potential links between the expression profiles of OPG, RANK, the pro-tumourigenic stimuli HGF and the bone microenvironment.

Suppression of molecules of interest using ribozyme transgenes. OPG or RANK expression was successfully targeted in MDA-MB-231 breast cancer cells following transfection with anti-OPG or anti-RANK ribozyme transgenes contained within a pEF6 plasmid. Reduced OPG transcript expression was seen in MDA-MB-231 ${ }^{\text {OPGKD }}$ cells compared to the MDA-MB-231 ${ }^{\text {pEF6 }}$ cells using both RT-PCR and $\mathrm{qPCR}$ (Fig. 1A and B). The result was subsequently confirmed at a protein level using western blotting (Fig. 1C).

Reduced RANK transcript expression was seen in MDA-MB-231 ${ }^{\text {RANKKD }}$ cells compared to the MDA-MB-231 ${ }^{\mathrm{pEF} 6}$ cells using both RT-PCR and qPCR (Fig. 1D and E). This was subsequently confirmed at a protein level using western blotting (Fig. 1F).

Impact on MDA-MB-231 breast cancer cell proliferation. MDA-MB-231 breast cancer cell proliferation over 5 days was not significantly altered after suppression of OPG compared to the control cells (Fig. 2A). Suppression of RANK in MDA-MB-231 breast cancer cells resulted in a statistically significant decrease in cell proliferation after 5-day incubation compared to the control cells (Fig. 2B, p=0.029). Individual $40 \mathrm{ng} / \mathrm{ml} \mathrm{HGF}$ and $50 \mu \mathrm{g} / \mathrm{ml} \mathrm{BME}$ treatments significantly increased MDA-MB-231 $1^{\mathrm{pEF} 6}$ cell proliferation after 5-day incubation compared to the untreated control (Fig. 2C, $\mathrm{p}=0.029$ ). A similar pattern was seen after incubation with a combined $40 \mathrm{ng} / \mathrm{ml} \mathrm{HGF}$ and $50 \mu \mathrm{g} / \mathrm{ml}$ BME treatment; however, this did not reach statistical significance. MDA-MB-231 ${ }^{\text {OPGKD }}$ (Fig. 2D) and MDA-MB-231 RANKKD (Fig. 2E) cell proliferation was less responsive to $\mathrm{HGF}$ and $\mathrm{BME}$ treatments compared to those observed in the MDA-MB-231 ${ }^{\mathrm{pEF} 6}$ cells. No statistically significant changes were observed in either of the suppressed cell lines compared to their respective untreated controls.

Impact on MDA-MB-231 breast cancer cell-matrix adhesion. Suppression of OPG in MDA-MB-231 breast cancer cells did not appear to affect cell-matrix adhesion (Fig. 3A). In contrast, 
A

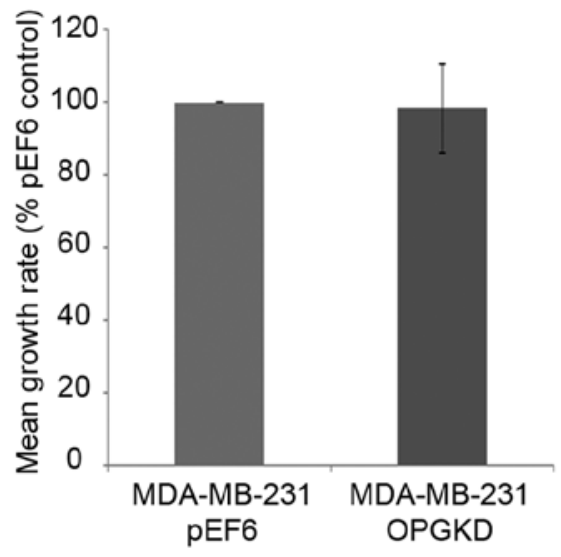

B

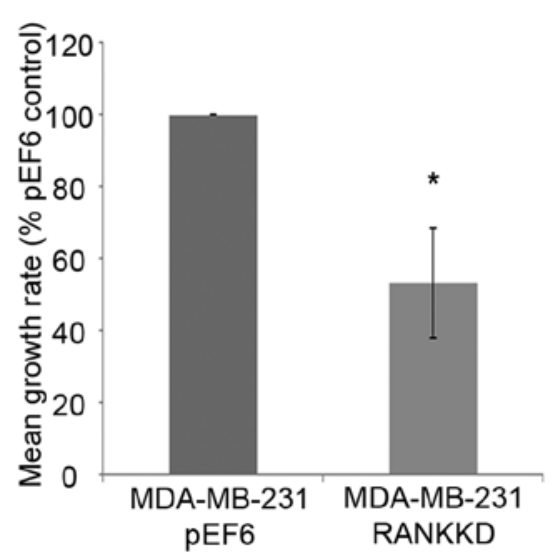

C

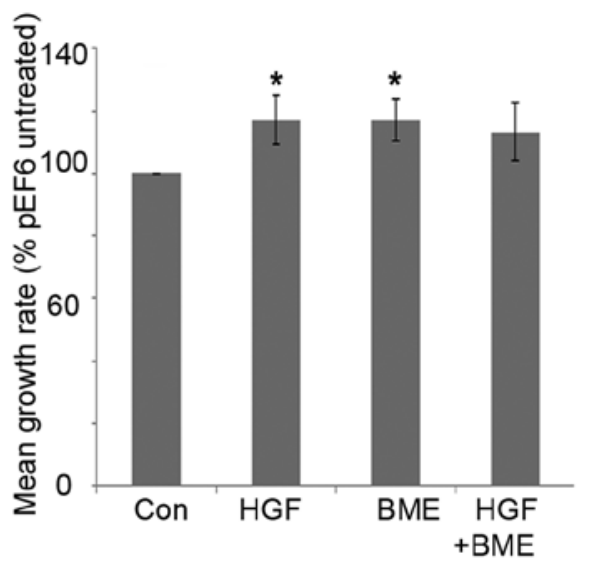

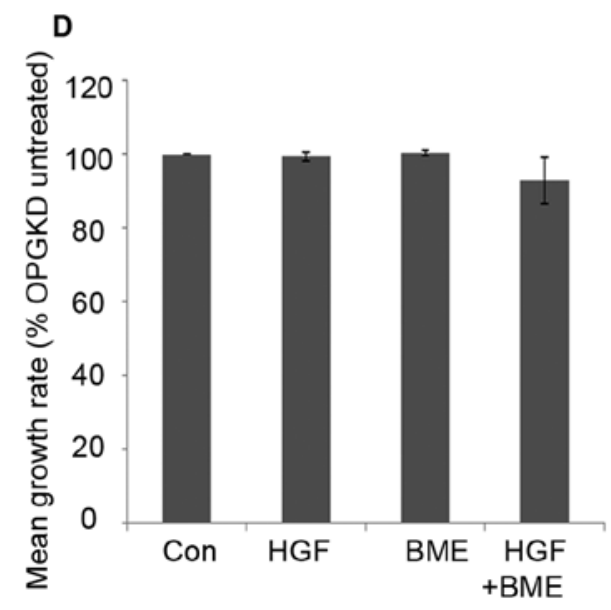

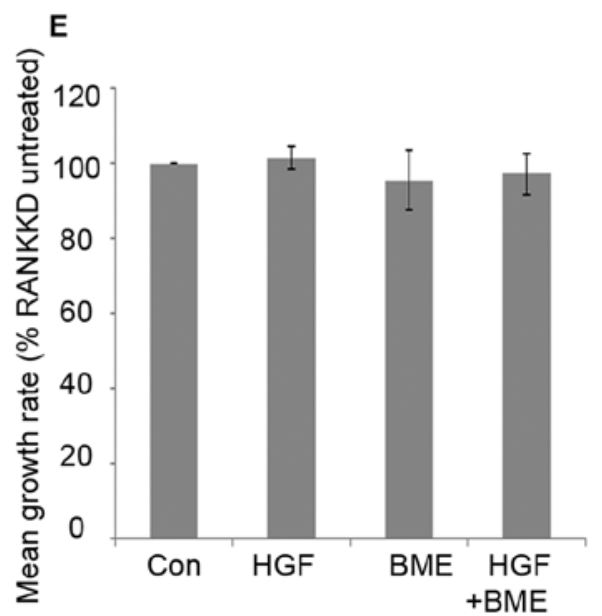

Figure 2. Impact of OPG and RANK knockdown on MDA-MB-231 cell proliferation in vitro. Suppression of OPG expression had no effect on MDA-MB-231 cell proliferation after 5-day incubation compared to MDA-MB-231 ${ }^{\mathrm{PEF}}$ control cells (A). Reduced RANK expression in MDA-MB-231 cells resulted in a significant decrease in cell proliferation after 5-day incubation compared with control cells (B). Treatment of the MDA-MB-231 ${ }^{\mathrm{EFF}}$ control cell line with $40 \mathrm{ng} / \mathrm{ml} \mathrm{HGF}, 50 \mu \mathrm{g} / \mathrm{ml}$ BME or a combination of $40 \mathrm{ng} / \mathrm{ml} \mathrm{HGF}$ and $50 \mu \mathrm{g} / \mathrm{ml}$ BME resulted in a significant increase in cell proliferation after 5-day incubation compared to the untreated cells (C). After 5-day treatment of MDA-MB-231 ${ }^{\text {OPGKD }}$ cells or MDA-MB-231 ${ }^{\text {RANKKD }}$ cells with $40 \mathrm{ng} / \mathrm{ml} \mathrm{HGF,} 50 \mu \mathrm{g} / \mathrm{ml}$ BME or a combination of $40 \mathrm{ng} / \mathrm{ml} \mathrm{HGF}$ and $50 \mu \mathrm{g} / \mathrm{ml}$ BME no changes were seen compared to the respective untreated cells (D and E). Data represent the mean of 4 independent repeats, error bars represent SEM. "p $\leq 0.05$.

suppression of RANK in MDA-MB-231 breast cancer cells resulted in a statically significant decrease in cell-matrix adhesion in vitro (Fig. 3B, $\mathrm{p}=0.029$ ). MDA-MB-231 ${ }^{\mathrm{pEF} 6}$ cell-matrix adhesion appeared unaffected under the influence of treatment with $40 \mathrm{ng} / \mathrm{ml} \mathrm{HGF}$ and/or $50 \mu \mathrm{g} / \mathrm{ml}$ BME (Fig. 3C). A similar trend was seen in the MDA-MB-231 ${ }^{\text {OPGKD }}$ cells treated individually with $40 \mathrm{ng} / \mathrm{ml} \mathrm{HGF}$ or $50 \mu \mathrm{g} / \mathrm{ml}$ BME (Fig. 3D), however, when these treatments were combined cell-matrix adhesion was significantly reduced compared to the untreated cells $(p=0.024)$. In the MDA-MB-231 ${ }^{\text {RANKKD }}$ cells treatment with $40 \mathrm{ng} / \mathrm{ml} \mathrm{HGF}$ and $/$ or $50 \mu \mathrm{g} / \mathrm{ml}$ BME did not appear to significantly affect cell-matrix adhesion (Fig. 3E).

Impact on MDA-MB-231 breast cancer cell motility. Suppression of OPG expression in MDA-MB-231 cells resulted in significantly increased cell motility in vitro compared to the control cells (Fig. 4A, p=0.029). In contrast, suppression of RANK in MDA-MB-231 breast cancer cells resulted in significantly decreased cell motility in vitro (Fig. $4 \mathrm{~B}, \mathrm{p} \leq 0.001$ ). When MDA-MB-231 ${ }^{\mathrm{pEF} 6}$ cells were treated with $40 \mathrm{ng} / \mathrm{ml}$
HGF cell motility was increased, however, this did not pass the statistical threshold (Fig. 4C). However, no noticeable effect was seen on MDA-MB-231 ${ }^{\mathrm{EFF} 6}$ cell motility when cells were treated with $50 \mu \mathrm{g} / \mathrm{ml}$ BME. When both treatments were combined MDA-MB-231 ${ }^{\mathrm{pEF} 6}$ cell motility was significantly increased compared to the untreated control cells (Fig. 4C, $\mathrm{p}=0.029)$. In contrast, treatment of MDA-MB-231 ${ }^{\text {OPGD }}$ cells with $40 \mathrm{ng} / \mathrm{ml} \mathrm{HGF}$ or $50 \mu \mathrm{g} / \mathrm{ml} \mathrm{BME} \mathrm{did} \mathrm{not} \mathrm{appear} \mathrm{to} \mathrm{impact}$ MDA-MB-231 cell motility compared to the untreated control (Fig. 4D). When these treatments were combined increased cell motility was observed compared to the untreated control cells, however, this trend also failed to reach the statistically significant threshold. Similar responses to the exogenous HGF and BME treatments were also seen in the MDA-MB-231 ${ }^{\text {RANK KD }}$ cells, in which cell motility was only marginally affected by these factors (Fig. 4E).

Impact on MDA-MB-231 breast cancer cell invasion. Suppression of OPG resulted in significantly increased cell invasiveness compared to the control cells (Fig. 5A, p=0.037). 
A

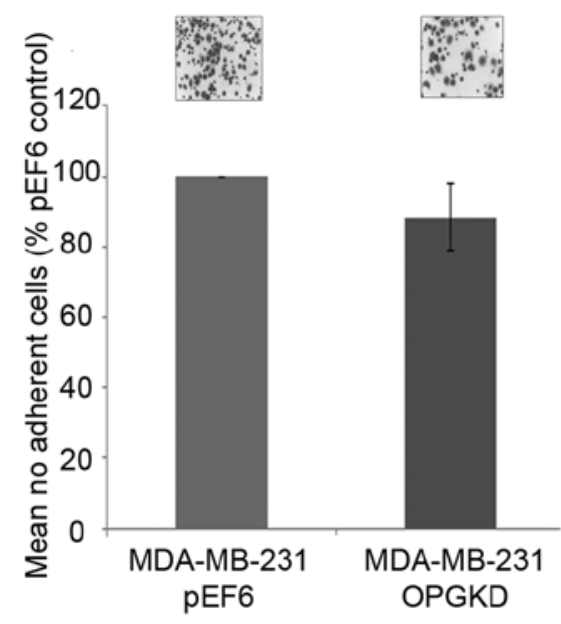

B

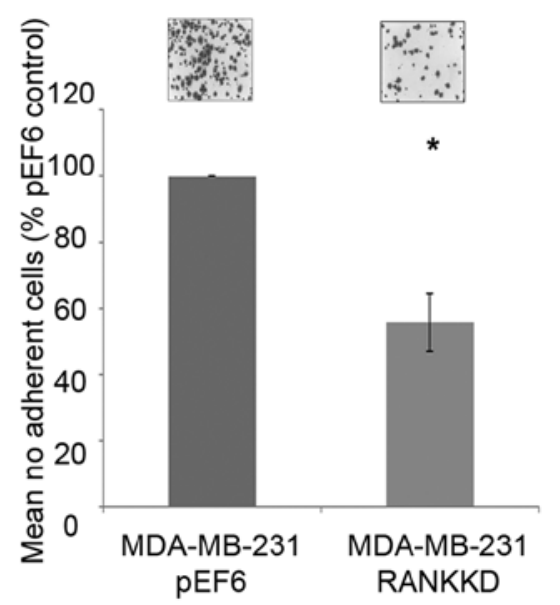

C

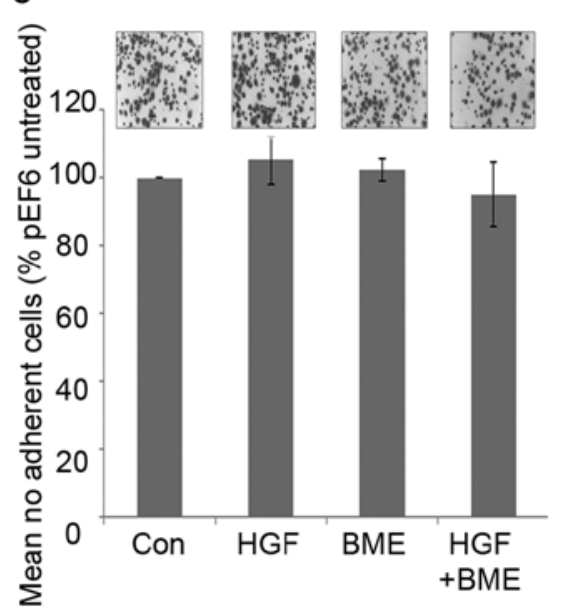

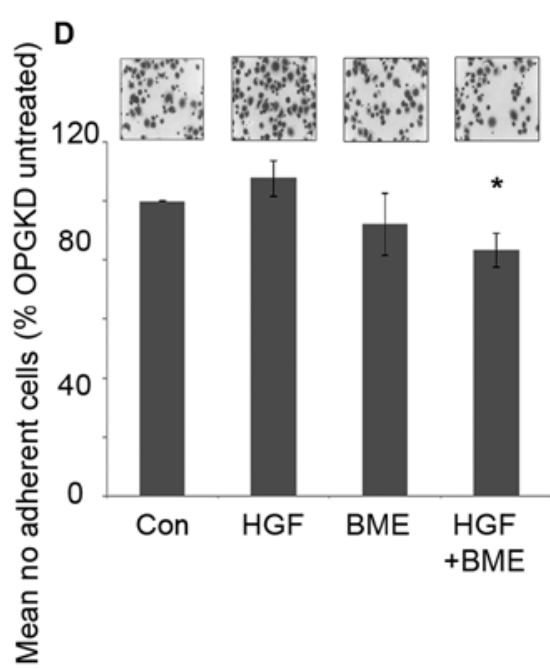

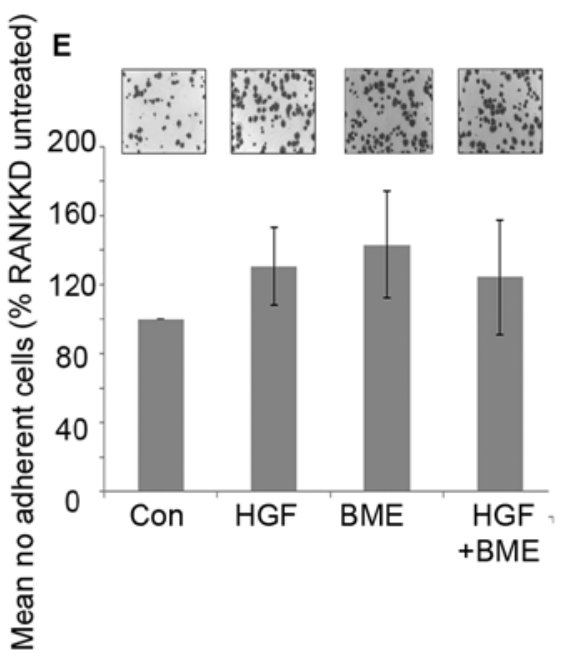

Figure 3. Impact of reduced OPG and RANK expression in MDA-MB-231 cells on cell-matrix adhesion in vitro. Reduced OPG expression did not alter MDA-MB-231 cell-matrix adhesion compared with control cells (A). Reduced RANK expression resulted in a significant decrease in MDA-MB-231 cell-matrix adhesion compared with control cells (B). When MDA-MB-231 $1^{\mathrm{pEF} 6}$ control cells were treated with $40 \mathrm{ng} / \mathrm{ml} \mathrm{HGF}$ or $50 \mu \mathrm{g} / \mathrm{ml} \mathrm{BME}$ or a combination of $40 \mathrm{ng} / \mathrm{ml} \mathrm{HGF}$ and $50 \mu \mathrm{g} / \mathrm{ml}$ BME did not significantly alter MDA-MB-231 cell-matrix adhesion (C). MDA-MB-231 ${ }^{\text {OPGKD }}$ cells treated with $40 \mathrm{ng} / \mathrm{ml} \mathrm{HGF}$ or $50 \mu \mathrm{g} / \mathrm{ml} \mathrm{BME}$ also did not alter cell-matrix adhesion, however, a combined of HGF and BME treatment significantly decreased cell matrix adhesion (D). MDA-MB-231 RANKKD cells treated with $40 \mathrm{ng} / \mathrm{ml}$ HGF, $50 \mu \mathrm{g} / \mathrm{ml}$ BME or combined HGF and BME did not affect cell-matrix adhesion compared to the untreated cells (E). Data represent the mean of 4 independent repeats, error bars represent SEM. ${ }^{*} \mathrm{p} \leq 0.05$.

However, suppression of RANK in MDA-MB-231 cells resulted in a significant decrease in breast cancer cell invasion in vitro compared to the control cells (Fig. 5B, p=0.002). Treatment of MDA-MB-231 $1^{\mathrm{pEF} 6}$ cells with $40 \mathrm{ng} / \mathrm{ml} \mathrm{HGF}$ or $50 \mu \mathrm{g} / \mathrm{ml} \mathrm{BME}$ increased cell invasion in vitro compared to untreated cells, however, these trends did not reach the statistically significant threshold (Fig. 5C). When these treatments were added in combination no noticeable effect on MDA-MB-231 cell invasion was observed. In contrast, when MDA-MB-231 ${ }^{\text {OPGKD }}$ cells were treated with $40 \mathrm{ng} / \mathrm{ml} \mathrm{HGF}$ or a combination of $40 \mathrm{ng} / \mathrm{ml}$ $\mathrm{HGF}$ and $50 \mu \mathrm{g} / \mathrm{ml} \mathrm{BME}$ significant reductions in cell invasion were observed compared to the untreated cells (Fig. 5D, $\mathrm{p}=0.002$ and 0.013 , respectively). The largest reduction in cell invasion was observed under the individual $50 \mu \mathrm{g} / \mathrm{ml}$ BME treatment; however, this trend did not reach statistical significance. MDA-MB-231 RANKKD cell invasion under both individual exogenous treatments increased in vitro compared to the untreated control cells in a similar trend to that observed in the MDA-MB-231 ${ }^{\mathrm{pEF} 6}$ control cells, though none of these changes reached a significant level (Fig. 5E). However, interestingly a combined treatment appeared to have little impact on breast cancer cell invasion.

\section{Discussion}

With the combined efforts of surgeons, oncologists and research, treatment options for primary breast cancer have improved. However, one aspect of the disease which still remains poorly understood and controlled is its metastatic spread, particularly to the bone. Through the recent licensing of Denosumab, the neutralising RANKL antibody, some progress has been achieved; however, there still remains no preventative measures or screening tools which can identify those most at risk. 

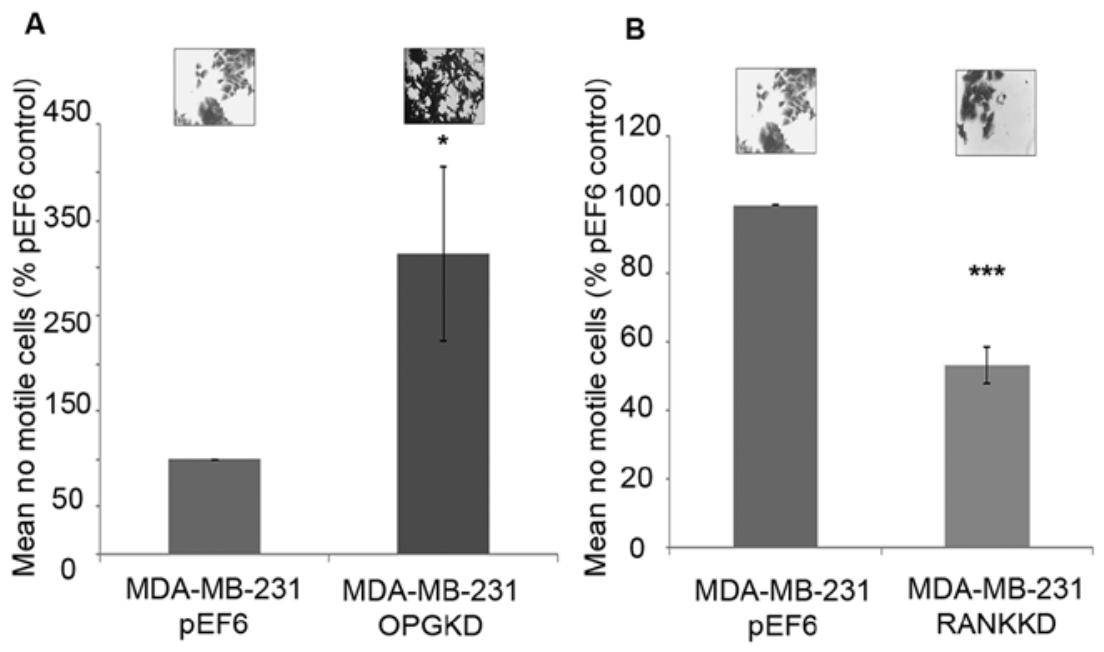

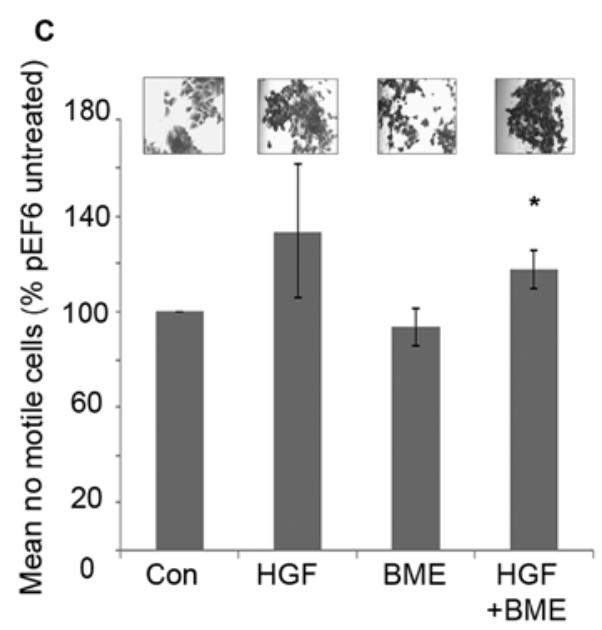

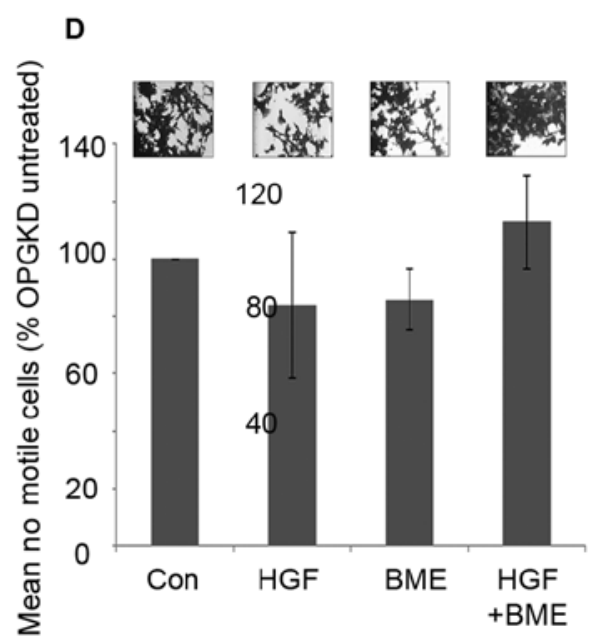

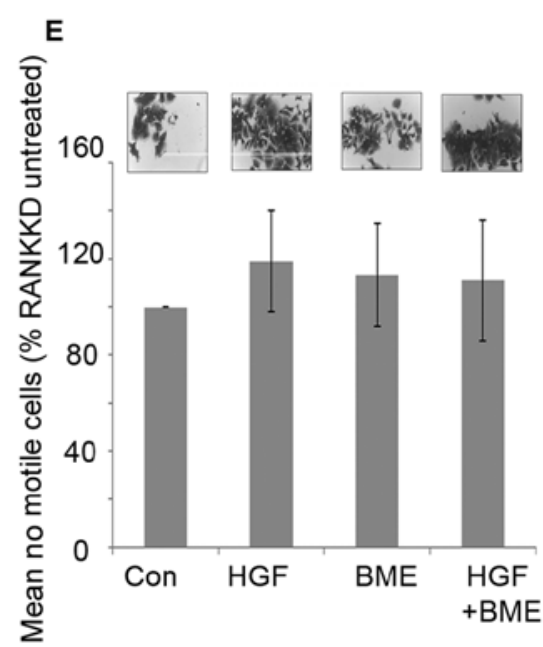

Figure 4. Effect of OPG and RANK knockdown on MDA-MB-231 cell motility. MDA-MB-231 ${ }^{\text {OPGKD }}$ cells showed significantly increased motility compared with MDA-MB-231 $1^{\mathrm{pEF} 6}$ control cells (A). Reduced RANK expression resulted in a significant decrease in MDA-MB-231 cell motility compared to MDA-MB-231 $1^{\mathrm{EFF} 6}$ control cells (B). Treatment of MDA-MB-231 $1^{\mathrm{EFF} 6}$ control cells with $40 \mathrm{ng} / \mathrm{ml} \mathrm{HGF}$ or $50 \mu \mathrm{g} / \mathrm{ml}$ BME did not significantly alter cell motility. However, a combination of $40 \mathrm{ng} / \mathrm{ml} \mathrm{HGF}$ and $50 \mu \mathrm{g} / \mathrm{ml} \mathrm{BME}$ significantly increased cell motility compared to the untreated control (C). Treatment of MDA-MB-231 $1^{\text {OPGKD }}$ or MDA-MB-231 ${ }^{\text {RANKKD }}$ cells with $40 \mathrm{ng} / \mathrm{ml} \mathrm{HGF}$ and $/$ or $50 \mu \mathrm{g} / \mathrm{ml}$ BME did not significantly impact cell motility (D and E, respectively). Data represent the mean of 4 independent repeats, error bars represent SEM. ${ }^{*} \mathrm{p} \leq 0.05,{ }^{* *} \mathrm{p} \leq 0.01,{ }^{* * *} \mathrm{p} \leq 0.001$.

Whilst many previous studies have considered the role OPG plays in the inhibition of TRAIL and thus apoptosis (15), few reports consider the molecular implications in breast cancer progression to the bone. Of interest from this study was the lack of proliferation response to the exogenous HGF and BME treatments in the OPG suppressed cells which had been seen in the control cells. Of similar interest was that this lack of response to the exogenous stimuli (HGF and BME) was also seen in the cell-matrix adhesion assays. This study has also highlighted the potential roles suppression of OPG may have in increasing breast cancer cell motility and invasion in addition to its role in preventing apoptosis. Suppression of OPG resulted in significantly more motile MDA-MB-231 breast cancer cells compared to the untreated control. However, also of interest was that the exogenous treatments did not appear to have any further effect on this cell function. Though suppression of OPG resulted in significantly increased cell invasion, of note was that all the exogenously added treatments resulted in decreased cell invasion. This is of particular interest because, though not reaching statistical significance in the control cell line, treatment with HGF or BME resulted in increases in cell invasion. This highlights that OPG may play an integral role in breast cancer cells homing to the bone environment. This present data therefore suggest that expression of OPG may result in the suppression of these aggressive cancer cell traits and may also contribute to the regulation of the MDA-MB-231 breast cancer cell response to various environmental stimuli, including HGF, once bone metastases have already been established. This study implies in vitro the targeting of OPG also results in a response suppression to the oncogenic factor HGF. This is an interesting observation given a number of reports which demonstrate the potential prognosis effect of its receptor, c-MET expression and its phosphorylated version could have on breast cancer survival (32). However, an in vivo study by Zinonos et al (33) suggested that pharmacological inhibition of OPG though beneficial for bone health (reduction in osteolysis) also resulted in an increase in formation of soft tissue metastases. This was supported by Weichhaus et al (34) demonstrating that suppression of OPG in a chick embryo model reduced metastasis. These data and that from 
A

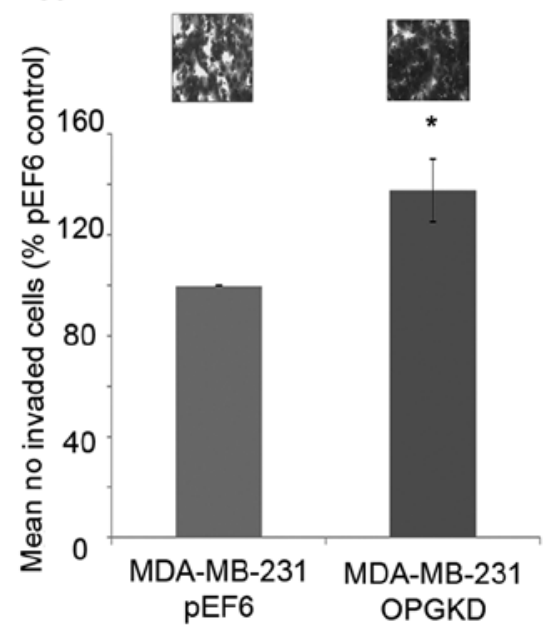

B

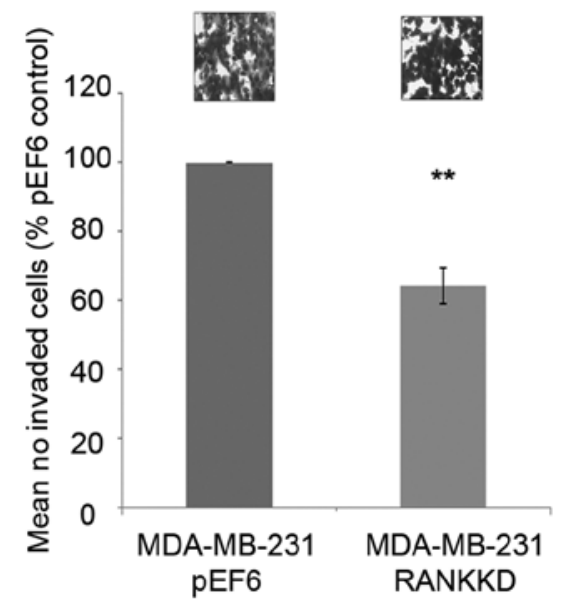

C

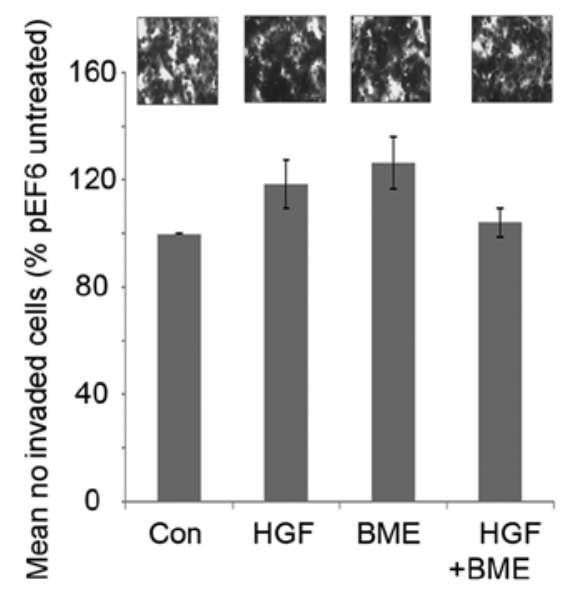

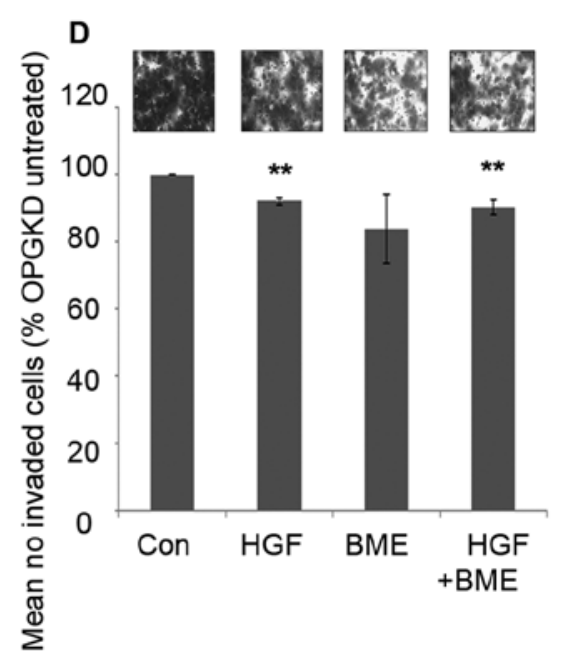

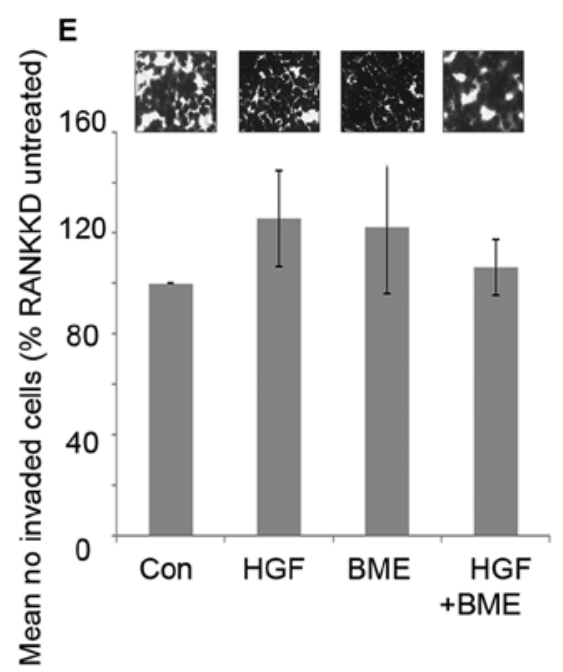

Figure 5. Impact of reduced OPG and RANK expression on MDA-MB-231 cell invasion in vitro. MDA-MB-231 ${ }^{\text {OPGKD }}$ cells showed significantly increased cell invasion compared with MDA-MB-231 ${ }^{\mathrm{pEF} 6}$ control cells (A). MDA-MB-231 ${ }^{\mathrm{RANKKD}}$ cells showed reduced cell invasion compared with MDA-MB-231 ${ }^{\mathrm{pEF} 6}$ control cells (B). Treatment of MDA-MB-231 ${ }^{\mathrm{pEF} 6}$ control cells with $40 \mathrm{ng} / \mathrm{ml} \mathrm{HGF,} 50 \mu \mathrm{g} / \mathrm{ml} \mathrm{BME}$ or a combination of $40 \mathrm{ng} / \mathrm{ml} \mathrm{HGF}$ and $50 \mu \mathrm{g} / \mathrm{ml} \mathrm{BME}$ do not impact cell invasion (C). Treatment of MDA-MB-231 ${ }^{\text {OPGKD }}$ cells with $40 \mathrm{ng} / \mathrm{ml} \mathrm{HGF}$ or a combination of $40 \mathrm{ng} / \mathrm{ml} \mathrm{HGF}$ and $50 \mu \mathrm{g} / \mathrm{ml} \mathrm{BME} \mathrm{resulted} \mathrm{in} \mathrm{a} \mathrm{significant}$ decrease in cell invasion (D). MDA-MB-231 RANKKD cells treated with $40 \mathrm{ng} / \mathrm{ml} \mathrm{HGF,} 50 \mu \mathrm{g} / \mathrm{ml} \mathrm{BME}$ or combined $40 \mathrm{ng} / \mathrm{ml} \mathrm{HGF}$ and $50 \mu \mathrm{g} / \mathrm{ml} \mathrm{BME}$ showed non-significant increases in cell invasion (E). Data represent the mean of 3 independent repeats, error bars represent $\mathrm{SEM}$. ${ }^{*} \mathrm{p}=\leq 0.05{ }^{* *} \mathrm{p} \leq 0.01$.

elsewhere in the scientific literature therefore suggest that the targeting of OPG in breast cancer may be a double edged sword $(35,36)$.

In contrast, the suppression of RANK in MDA-MB-231 breast cancer cells resulted in decreased responses in all the traits studied. Cell proliferation was significantly decreased after 5-day incubation compared to the control. Similar lack of response to the exogenous treatments was seen in the RANK suppressed cells. Interestingly, individual HGF or BME treatments increased cell-matrix adhesion and cell invasion in the RANK suppressed cells, though these did not pass the threshold for statistical significance. Most previous studies have overexpressed RANK in breast cancer models and reported increases in aggressive cell behaviour, including increased cell migration and invasion as well as greater metastatic bone colonisation (37). Casimiro et al (38) in their study found a link between bone-seeking RANK positive subclones of MDA-MB-231 cells and increased cell migration and invasion through the RANKL JNK and ERK 1/2 signalling pathway.
This demonstrates that the three molecules, OPG, RANK and RANKL, originally linked to regulation of bone turnover have other roles, potentially even pro-metastatic ones in breast cancer. The data reported here suggest that the targeting of RANK affects breast cancer cell behaviour associated with a metastatic phenotype (i.e., migration and invasion) in its own right, changes which subsequently remained unaltered when exposed to a bone-like environment. This therefore opens the possibility to explore the combination of dual therapies which combine targeting of breast cancer cell expressed RANKL (Denosumab) and RANK.

The human body is an intricate combination of a variety of cells and factors which could never be replicated in a 2-D model, possibly accounting for the disparity between the in vitro results and our previously published clinical data. Isolating OPG and RANK in this model system has demonstrated, particularly with OPG that they may play roles in bone metastases associated with breast cancer. Further scientific study is now necessary to fully understand the downstream 
molecules of OPG which influence this tumourigenic behaviour beyond the inhibition of TRAIL-induced apoptosis.

\section{Acknowledgements}

The authors would like to thank Cancer Research Wales for supporting this study.

\section{References}

1. Coleman RE: Clinical features of metastatic bone disease and risk of skeletal morbidity. Clin Cancer Res 12: S6243-S6249, 2006.

2. Roodman GD: Mechanisms of bone metastasis. N Engl J Med 350: 1655-1664, 2004.

3. Coleman RE: Metastatic bone disease: Clinical features, pathophysiology and treatment strategies. Cancer Treat Rev 27: 165-176, 2001.

4. Paget S: The distribution of secondary growths in cancer of the breast. 1889. Cancer Metastasis Rev 8: 98-101, 1989.

5. Siclari VA, Guise TA and Chirgwin JM: Molecular interactions between breast cancer cells and the bone microenvironment drive skeletal metastases. Cancer Metastasis Rev 25: 621-633, 2006.

6. Fidler IJ and Poste G: The 'seed and soil' hypothesis revisited. Lancet Oncol 9: 808, 2008.

7. Weilbaecher KN, Guise TA and McCauley LK: Cancer to bone: A fatal attraction. Nat Rev Cancer 11: 411-425, 2011.

8. Boyce BF and Xing L: Functions of RANKL/RANK/OPG in bone modeling and remodeling. Arch Biochem Biophys 473: 139-146, 2008.

9. Hakeda Y, Kobayashi Y, Yamaguchi K, Yasuda H, Tsuda E, Higashio K, Miyata T and Kumegawa M: Osteoclastogenesis inhibitory factor (OCIF) directly inhibits bone-resorbing activity of isolated mature osteoclasts. Biochem Biophys Res Commun 251: 796-801, 1998.

10. Yasuda H, Shima N, Nakagawa N, Mochizuki SI, Yano K, Fujise N, Sato Y, Goto M, Yamaguchi K, Kuriyama M, et al: Identity of osteoclastogenesis inhibitory factor (OCIF) and osteoprotegerin (OPG): A mechanism by which OPG/OCIF inhibits osteoclastogenesis in vitro. Endocrinology 139: 1329-1337, 1998.

11. Ibrahim T, Sacanna E, Gaudio M, Mercatali L, Scarpi E, Zoli W, Serra P, Ricci R, Serra L, Kang Y, et al: Role of RANK, RANKL, $\mathrm{OPG}$, and CXCR4 tissue markers in predicting bone metastases in breast cancer patients. Clin Breast Cancer 11: 369-375, 2011.

12. Mercatali L, Ibrahim T, Sacanna E, Flamini E, Scarpi E, Calistri D, Ricci M, Serra P, Ricci R, Zoli W, et al: Bone metastases detection by circulating biomarkers: OPG and RANK-L. Int J Oncol 39: 255-261, 2011.

13. Van Poznak C, Cross SS, Saggese M, Hudis C, Panageas KS Norton L, Coleman RE and Holen I: Expression of osteoprotegerin (OPG), TNF related apoptosis inducing ligand (TRAIL), and receptor activator of nuclear factor kappaB ligand (RANKL) in human breast tumours. J Clin Pathol 59: 56-63, 2006.

14. Neville-Webbe HL, Cross NA, Eaton CL, Nyambo R, Evans CA, Coleman RE and Holen I: Osteoprotegerin (OPG) produced by bone marrow stromal cells protects breast cancer cells from TRAIL-induced apoptosis. Breast Cancer Res Treat 86: 269-279, 2004.

15. Holen I, Cross SS, Neville-Webbe HL, Cross NA, Balasubramanian SP, Croucher PI, Evans CA, Lippitt JM, Coleman RE and Eaton CL: Osteoprotegerin (OPG) expression by breast cancer cells in vitro and breast tumours in vivo - a role in tumour cell survival? Breast Cancer Res Treat 92: 207-215, 2005.

16. Nicolin V and Narducci P: Soluble TRAIL could enhance bone destruction acting on Rank-ligand in estrogen-independent human breast cancer cell line MDA-MB-231. Acta Histochem 112: 189-192, 2010.

17. Michalopoulos G, Houck KA, Dolan ML and Leutteke NC: Control of hepatocyte replication by two serum factors. Cancer Res 44: 4414-4419, 1984.

18. Nakamura T, Nawa K and Ichihara A: Partial purification and characterization of hepatocyte growth factor from serum of hepatectomized rats. Biochem Biophys Res Commun 122: 1450-1459, 1984.
19. Russell WE, McGowan JA and Bucher NL: Biological properties of a hepatocyte growth factor from rat platelets. J Cell Physiol 119: 193-197, 1984.

20. Jiang WG, Martin TA, Parr C, Davies G, Matsumoto K and Nakamura T: Hepatocyte growth factor, its receptor, and their potential value in cancer therapies. Crit Rev Oncol Hematol 53: 35-69, 2005.

21. Parikh RA, Wang P, Beumer JH, Chu E and Appleman LJ: The potential roles of hepatocyte growth factor (HGF)-MET pathway inhibitors in cancer treatment. Onco Targets Ther 7: 969-983, 2014.

22. Davies S and Jiang WG: ALCAM, activated leukocyte cell adhesion molecule, influences the aggressive nature of breast cancer cells, a potential connection to bone metastasis. Anticancer Res 30: 1163-1168, 2010.

23. Sanders AJ, Parr C, Mason MD and Jiang WG: Suppression of hepatocyte growth factor activator inhibitor-1 leads to a more aggressive phenotype of prostate cancer cells in vitro. Int J Mol Med 20: 613-619, 2007.

24. Yuan Z, Sanders AJ, Ye L, Wang Y and Jiang WG: Knockdown of human antigen $\mathrm{R}$ reduces the growth and invasion of breast cancer cells in vitro and affects expression of cyclin D1 and MMP-9. Oncol Rep 26: 237-245, 2011.

25. Zuker M: Mfold web server for nucleic acid folding and hybridization prediction. Nucleic Acids Res 31: 3406-3415, 2003.

26. Jiang WG, Hiscox S, Hallett MB, Horrobin DF, Mansel RE and Puntis MC: Regulation of the expression of E-cadherin on human cancer cells by gamma-linolenic acid (GLA). Cancer Res 55: 5043-5048, 1995.

27. Jiang WG, Hiscox S, Singhrao SK, Nakamura T, Puntis MC and Hallett MB: Inhibition of HGF/SF-induced membrane ruffling and cell motility by transient elevation of cytosolic free $\mathrm{Ca}^{2+}$. Exp Cell Res 220: 424-433, 1995.

28. Rosen EM, Carley W and Goldberg ID: Scatter factor regulates vascular endothelial cell motility. Cancer Invest 8: 647-650, 1990.

29. Albini A, Iwamoto Y, Kleinman HK, Martin GR, Aaronson SA, Kozlowski JM and McEwan RN: A rapid in vitro assay for quantitating the invasive potential of tumor cells. Cancer Res 47: 3239-3245, 1987.

30. Parish CR, Jakobsen KB and Coombe DR: A basement-membrane permeability assay which correlates with the metastatic potential of tumour cells. Int J Cancer 52: 378-383, $1992 .$.

31. Owen S, Ye L, Sanders AJ, Mason MD and Jiang WG: Expression profile of receptor activator of nuclear- $\kappa \mathrm{B}$ (RANK), RANK ligand (RANKL) and osteoprotegerin (OPG) in breast cancer. Anticancer Res 33: 199-206, 2013.

32. Raghav KP, Wang W, Liu S, Chavez-MacGregor M, Meng X, Hortobagyi GN, Mills GB, Meric-Bernstam F, Blumenschein GR Jr and Gonzalez-Angulo AM: cMET and phospho-cMET protein levels in breast cancers and survival outcomes. Clin Cancer Res 18: 2269-2277, 2012.

33. Zinonos I,Luo KW,Labrinidis A, Liapis V, Hay S, Panagopoulos V, Denichilo M, Ko CH, Yue GG, Lau CB, et al: Pharmacologic inhibition of bone resorption prevents cancer-induced osteolysis but enhances soft tissue metastasis in a mouse model of osteolytic breast cancer. Int J Oncol 45: 532-540, 2014.

34. Weichhaus M, Segaran P, Renaud A, Geerts D and Connelly L: Osteoprotegerin expression in triple-negative breast cancer cells promotes metastasis. Cancer Med 3: 1112-1125, 2014.

35. Body JJ, Greipp P, Coleman RE, Facon T, Geurs F, FermandJP, Harousseau JL, Lipton A, Mariette X, Williams CD, et al: A phase I study of AMGN-0007, a recombinant osteoprotegerin construct, in patients with multiple myeloma or breast carcinoma related bone metastases. Cancer 97 (Suppl): 887-892, 2003.

36. Chanda D, Isayeva T, Kumar S, Siegal GP, Szafran AA, Zinn KR, Reddy VV and Ponnazhagan S: Systemic osteoprotegerin gene therapy restores tumor-induced bone loss in a therapeutic model of breast cancer bone metastasis. Mol Ther 16: 871-878, 2008.

37. Blake ML, Tometsko M, Miller R, Jones JC and Dougall WC: RANK expression on breast cancer cells promotes skeletal metastasis. Clin Exp Metastasis 31: 233-245, 2014.

38. Casimiro S, Mohammad KS, Pires R, Tato-Costa J, Alho I, Teixeira R, Carvalho A, Ribeiro S, Lipton A, Guise TA, et al: RANKL/RANK/MMP-1 molecular triad contributes to the metastatic phenotype of breast and prostate cancer cells in vitro. PLoS One 8: e63153, 2013. 